Article

\title{
Contemporary Social Theory as a Tool to Understand the Experiences of Disabled Students in Higher Education
}

\author{
Jonathan Harvey \\ Institute of Education, Plymouth Marjon University, Derriford, PL6 8BH, UK; E-Mail: jharvey@marjon.ac.uk
}

Submitted: 7 June 2018 | Accepted: 16 August 2018 | Published: 6 December 2018

\begin{abstract}
This is a conceptual article which seeks to consider the use of contemporary social theory to help understand the experience of disabled students in higher education. The use of social theoretical insights has been criticised by many as demonstrating a lack of engagement with the everyday experiences of disabled people. Work which strives to embed theoretical insights into the study of disability has also been criticised for lacking engagement with the 'reality' of impairment. In this article I intend to address some of these criticisms by suggesting some ways in which the use of contemporary social theory may provide an explanatory tool which disentangles confusion regarding the journey undertaken by the disabled student. I will discuss how the writings of several social theorists may be helpful in making sense of disabled student journeys. I will begin by discussing why the work of Jacques Derrida can be useful in this regard. These writings will be considered alongside a debate which draws on the writings of Michel Foucault on the use of power in contemporary higher education institutions. I will critically discuss the theoretical insights of Deleuze and Guattari and their offerings on the notion of 'becoming'. I will then critically interrogate the work of Rosi Braidotti and apply these to a re-imagining of the disabled student journey. The writings of these important theorists have been used before to explore the experiences of disabled people. However, this article is unique in that it proposes that these writings can be used to demystify the experiences of disabled students in higher education. I suggest some ways the work of Derrida, Foucault, Deleuze and Guattari and Braidotti enable a greater understanding of my personal student journey. I suggest that they could be used to make sense of a far wider range of student journeys. I conclude the article by offering a model which utilises some important aspects of these theoretical insights.
\end{abstract}

\section{Keywords}

contemporary social theory; disability; higher education; postsecondary education; Social Security Disability Insurance; student; Supplemental Security Income

\section{Issue}

This article is part of the issue "Students with Disabilities in Higher Education", edited by Geert Van Hove (Ghent University, Belgium/VU Amsterdam, The Netherlands), Minne Bakker (VU Amsterdam, The Netherlands) and Alice Schippers (Disability Studies in the Netherlands/VU Amsterdam, The Netherlands).

(C) 2018 by the author; licensee Cogitatio (Lisbon, Portugal). This article is licensed under a Creative Commons Attribution 4.0 International License (CC BY).

\section{Introduction}

The study of disability and impairment provides the opportunity to apply theoretical insights to lived experiences. The study of disability and impairment is quite rightly underpinned by the experiences of disabled people. However, it has been noted that when lived experiences remain on the outside of the realms of theoretical analysis, they are less mobile and lack the ability to resonate with the lives of others (Goodley, Hughes, \& Davis, 2012; Goodley, Lawthom, \& Runswick Cole, 2014; Roets \& Braidotti, 2012; Van Trigt, Kool, \& Schippers, 2016; Vandekinderen \& Roets, 2016). In contrast, there are authors who cite the complexities that are generated by the use of theory in aiding understanding of the experiences of disabled people (Vehmas \& Watson, 2014; Watson, 2012). Furthermore, it has been stated that the journey through higher education-whether it be con- 
cerning disabled or non-disabled people-is under theorised and relies on taken for granted 'truths' rather than sophisticated theoretical ideas to aid understanding of student journeys (Strom, 2018; Taylor \& Harris-Evans, 2018; Wang, 2015). Consequently, it would be beneficial to generate discussion regarding the usefulness of social theory in the analysis of the journey of the disabled student.

In this article, I seek to contribute to the debate surrounding the use of social theory to explain the experience of disabled people by suggesting some ways in which the experience of disabled students may benefit from a robust analysis from contemporary social theory. I will apply these theoretical ideas and critically discuss the ways in which they may make those experiences more understandable. In suggesting theory may enhance the understanding of disabled students' experiences, I aim to make the process of attending university as a disabled person easier for others in the future.

In what follows I use the theoretical writings of Derrida, Foucault, Deleuze and Guattari and Rosi Braidotti to question discourses of disability that present opposition to the application of theory to aid understanding the experiences of disabled people (Watson, 2012). Following Goodley et al. (2012), I make no excuses for the use of 'intellectual plunder' (p. 315) as I seek to explore how theoretical ideas can help demystify the student experience of higher education and I take the view that:

Any intellectual system or social theory is fair game when it comes to building a case for emancipation or for sharpening the tools that are of value in opposing discrimination, exclusion and oppression. (Goodley et al., 2012, pp. 315-316)

I am a disabled person who has navigated the higher education system. Thus, I feel I am well-placed to interrogate the process from the perspective of the disabled student, person interested in the journeys of disabled students, and as a lecturer in special educational needs and disability studies. I have stated elsewhere that having more than one perspective on a subject increases the epistemological authority of the assertions one can make (Harvey, 2017; Letherby, Scott, \& Williams, 2012).

The situation regarding funding is ever-changing and this is exemplified through recent changes in the system (Student Loans Company, 2018). Additionally, any 'group' of people such as disabled students, should not be considered a singular, homogenous entity. The everchanging social landscape of student funding, together with the vast differences in student needs, dictates that a firm grasp of contemporary social theory is important in reaching a sophisticated understanding of student experiences. I begin by detailing my journey through higher education before returning to my personal experiences once again at the end of the article to demonstrate what viewing experiences of higher education through the lens of these theorists can offer.

\section{My Journey through the Higher Education System}

My first encounter with university came when I was 19 years old when I went to university to study physiotherapy (a three-year course in the UK). However, at the age of 21 (2003), I sustained a severe traumatic brain injury which left me physically unable to complete the course. I have written about my rehabilitation experiences elsewhere in more detail (Harvey, 2018). In 2007, I returned to university as a disabled student. I completed an undergraduate degree (health and social care studies), Master of Science degree (social research), and a PhD (a sociological approach to acquired brain injury and identity). Throughout my journey, I received fantastic support from both university staff and my peers. Reflecting on my experiences with the help of social theory has made the process of gaining meaning from and understanding my journey, far easier. Through exploring various theoretical viewpoints and relating them to some of the difficulties that disabled students may encounter, I hope to make this journey smoother for others in the future. I will now discuss how the writings of Jacques Derrida can relate to the presence of disabled students in higher education.

\section{The Insights of Jacques Derrida}

Jacques Derrida was a French philosopher born in 1930. $\mathrm{He}$ is most well-known for the idea of deconstruction, which is essentially stripping a concept back to its constituent parts to allow close inspection of each part (Stocker, 2006). I feel it is important to analyse disabled student journeys through a Derridan lens as the term 'deconstruction' aligns well with an exploration of disabled people's experiences. Deconstruction also entails a rejection of common-sense 'truths', something that is at the heart of much contemporary disability studies writings (Goodley et al., 2012; Harvey, 2017, 2018). Indeed, although Derrida did not refer to disability specifically, it can be said that his opposition of dualism can be said to be at the core of the contemporary view that no longer sees disability as a polar opposite of ability (Harpur, 2012). Furthermore, Derrida would suggest that the very notion of 'inclusion' reinforces the divide that exists between disabled and non-disabled students. Perhaps it would be better to reconceptualise higher education as a space where 'the student' is classified as the heterogeneous entity that is engaged with the gaining of knowledge amidst an environment of reciprocity, interdependence and affirmation. This will be discussed more when reference is provided to the work of Rosi Braidotti.

Derrida's criticism of the 'dishonest pursuit of certainty that shapes reason' (Corker \& Shakespeare, 2002) is, I would argue, an interesting way of theorising the presence of disabled students in higher education. Many disabled students who pass through university have resisted the power of common-sense understandings of life which would state that a university education is not a 'realistic' option. Due in part to the much-cited fluidity of 
the contemporary world, the landscape is ever-changing for disabled individuals who are interested in pursuing a university education.

For example, technological advances have dictated that students-who would have once found it difficult to attend university-can now purchase specific items of assistive technology that are designed to support the learning of disabled students in higher education institutions (Seale, Georgeson, Mamas, \& Swain, 2015). Furthermore, it has been argued that technology has developed to such an extent that 'mainstream' electronic devices (smartphones, MP3 players, and computers) perform similar functions to items that were once 'reserved' for the disabled person (Tripathi, 2012). Indeed, it is likely that Derrida would have seen little need for labels such as 'disabled student' which arguably merely serves to mark out differences between disabled students and their non-disabled peers. This view is counterbalanced by one that suggests the importance of gaining access to services (such as the disabled students allowance in the UK) which is gained through the use of such labels.

Then, applying a framework that draws on the writings of Derrida to make sense of the experiences of disabled students would focus on an ethical approach to higher education. This ethical approach would embrace the most slippery divide between disabled and non-disabled bodies (Price \& Shildrick, 2002). Such an approach would classify learners as just that, rather than 'disabled learners' or 'non-disabled learners'. All students would be on a journey which is concerned with education notwithstanding the corporeal features of the individual student.

The use of labels for disabled people is very much entangled with the debate surrounding power. Therefore, the work of Michel Foucault demands a particularly robust consideration in this debate regarding disabled students in higher education.

\section{Michael Foucault}

Foucault was also a French philosopher. Much of Foucault's work sought to examine the way power is used in social practice (Lemke, 2015; Tremain, 2015). The writings of Foucault have been used to make sense of a host of disabled people's experiences (Goodley et al., 2012; Tremain, 2015). It would therefore seem sensible to explore the lives of disabled students through a Foucauldian lens. In this discussion, I seek not to highlight the ways in which power is seen as a merely repressive concept in the lives of disabled students, but rather the way the use of power subtly dictates the lives of students on an everyday basis:

The most effective exercise of power, according to Foucault, consists in guiding possibilities of conduct and putting in order the possible outcomes. The concealment of these practices, these limits of possible conduct, allows the discursive formation in which they circulate to be naturalised and legitimised. That is to say, the production of these seeming acts of choice (these limits of possible conduct) on the everyday level of the subject makes possible the consolidation of more hegemonic structures. (Tremain, 2015, p. 8)

In terms of disabled students then, Foucault's work could be very useful in determining the way impairment may restrict the choice of the disabled student. Reflecting on my own experience of being a disabled student in higher education, this idea resonates with me greatly. During the process of choosing an appropriate course to study, I was immediately put off by any course which contained a significant amount of examinations as the mode of assessment. This was because of my impairment and the way that I would need someone to write my answers for me. It would be interesting to establish the proportion of students who make similar choices. Arguably this establishes the way that social theoretical insights can be used at the everyday level to explain the way that impairment can and does create added complexities for disabled people. However, it has been suggested that a Foucauldian analysis limits the attribution of agency to the choices disabled people make (Hughes, 2005).

In response to this criticism, I must stress that I do not wish to categorise the way impairment dictates certain decisions in a purely 'melancholic' way (Roets \& Braidotti, 2012). It is important that there is recognition of the capacity of the disabled student to acknowledge the presence of these complexities and integrate them into the choices they make. Interestingly, there is literature that highlights the way that disabled and non-disabled students face similar challenges when negotiating assessments in higher education (Madriaga et al., 2010). Therefore, when stating the capacity of the disabled student to make an informed choice, it is not simply a case of the disabled student 'overcoming' impairment that has been much criticised in British social model disability studies literature (Oliver, 2013). Rather, it is the demonstration of the way disabled people can and do rise up to the challenges that a disabling society offers (Campbell, 2009; Goodley, 2014), together with an appreciation of the way that identity is a wholly fluid concept which is highly changeable amongst disabled and non-disabled people alike.

A contemporary development in the higher educational landscape is the growing influence of neoliberalism, subjecting higher education to market forces. Indeed, stark warnings have been given regarding the role of universities within the knowledge economy particularly around assessment practices and governance (Torrance, 2017). Assessments such as the research excellence framework (REF) and the National Student Survey (NSS) are now hugely influential in determining the level of funding universities receive. This development has been widely criticised (Bessant, Robinson, \& Ormerod, 2015; Nixon, Scullion, \& Hearn, 2018; Olssen, 2016) par- 
ticularly in the way that it prevents academics from having the ability to shape their own institutions. The increasing classification of students as 'consumers' of university resources, may have severe consequences for disabled students as they seek to learn in an environment which promotes the importance of notions such as selfdetermination and independence (Mitchell, 2017). For these reasons, I believe situating student experiences within a theoretical landscape such as the one provided by Michel Foucault is, I would argue, very useful in reaching a sophisticated understanding of the experiences of disabled students in higher education. I now move on to discuss some ways in which the philosophical writings of Deleuze and Guattari can relate to the journey of disabled students through higher education.

\section{Deleuze and Guattari}

Deleuze and Guattari provide a blend of philosophy which also seeks to stray far away from common-sense understandings of life. In their text $A$ Thousand Plateus (Deleuze \& Guattari, 1987) the concepts of the rhizome and the nomad provide a way of viewing life 'as if it were not a linear, pre-determined entity with a definite 'end in sight', but instead as a journey with unforeseen checkpoints along the way' (Harvey, 2018, p. 95). The writings of Deleuze and Guattari have been used to explore the experiences of disabled people before (Goodley, 2014, 2016; Goodley et al., 2012; Madriaga \& Goodley, 2010). Therefore, I consider these insights to be most suitable to investigate the lives of disabled students. Indeed, when commenting on the use of the work of Deleuzue and Guattari to explore the experiences, Strom (2018) criticises the way that the writings of Deleuze and Guattari are all too often dismissed as being inaccessible and are not used in a sophisticated analysis of higher education. Strom (2018) provides an analysis of her own educational journey through a framework devised in conjunction with the writings of Deleuze and Guattari. In her account Strom (2018) highlights the nonlinearity of her journey. It is stated that:

Reflecting on my own non-linear journey from a teacher who had no use for theory or philosophy, to one whose career (at least in part) hinges on it, I believe now that both the inaccessibility of language and the discourses surrounding these bodies of thought probably played a part in my initial resistance to engaging with them. (Strom, 2018, p. 112)

The idea that life is not a linear and predetermined entity also resonates with my own journey through education and appears to represent the way that many students would feel that their path to higher education has taken. I suggest that an approach to higher education that views the journey as not a fixed, predetermined entity with inevitable hierarchical results is helpful. Such classifications of student journeys (both disabled and non- disabled) would celebrate the unknowable and unforeseen benefits of such a journey which is characterised by the gaining of experience, rather than the acquisition of a qualification.

Another useful metaphor offered by Deleuze and Guattari is that of the map. A map highlights the way there are many ways to arrive at a checkpoint. A map can also be 'torn, reversed, adapted to any kind of mounting, reworked by any individual, group, or social formation' (Deleuze \& Guattari, 1987, pp. 13-14). When related to the presence of disabled students at higher education institutions, this indicates that there is no single 'correct' way to navigate higher education, but rather there are many different ways. According to the philosophy of Deleuze and Guattari, a journey through higher education is not the end of a journey. Indeed, I would suggest that attendance in higher education is seen as a stepping stone in life rather than the final destination. The extent to which this is considered the case for disabled students as well as non-disabled students is arguable. The way universities attract students using a systematic approach based around statements, study objectives, learning activities, curriculum materials, assessment, and learning outcomes is termed curriculum mapping (Wang, 2015). The concept of curriculum mapping in higher education has been criticised (Wang, 2015) for its failure to sufficiently engage with the myriad possibilities attending university can provide. Rather, curriculum mapping (in its current form) is said to be akin to tracing, whereby creativity is stifled at the expense of linear development. Higher education institutions produce homogenous, predictable students who have the tools to be economically successful but are unable to live truly fulfilling lives. Wang (2015) concludes by stating that:

By knowing the world, students open their minds and expand their lives. Students should not only be successful in tracing an entrepreneurial self; receiving a higher education has the potential to free them from a pre-designed self by mapping the self in other ways. Therefore, the purpose of curriculum mapping is to educate a cartographer to create his or her new life. (Wang, 2015, p. 1558, emphasis in original)

The transition in life that attendance at higher education represents has been marked as being an under theorised concept which is plagued by common-sense and takenfor-granted assumptions regarding what this transition actually means (Gale \& Parker, 2014; Taylor \& HarrisEvans, 2018). It is stated that far too often transition is a concept that is thought of in a linear way, as a pathway from school to higher education. However, in practice this is often not the case (Gale \& Parker, 2014) and it would seem sensible to suggest that disabled students do not always take the 'typical' pathway to university. Indeed, if a framework that enables greater understanding of the importance of experience in the transition to higher education were used to make sense of student 
journeys, this would arguably allow greater space for the celebration of the gaining of experience in the nontraditional spheres of education.

When discussing the contribution of the work of Deleuze and Guattari to disability studies, Roets and Braidotti (2012) call for a celebration of the diversity of bodies and minds. In their view:

This produces a significant shift from the notion of an oppositional and split disabled/non-disabled dichotomy to an open-ended, relational vision of interdependent subjects. (Roets \& Braidotti, 2012, p. 175)

In relation to higher education, a significant departure from a disabled/non-disabled split, would produce a very different environment for the disabled student. It has been argued (Madriaga \& Goodley, 2010) that a higher education system that moves away from these dichotomies which focus on so-called deficits and instead towards a system which embraces the uncertain desires of students would be a useful development. Following this, then, it would seem sensible to suggest that the reflections of disabled students are a vital source of information in creating a truly inclusive higher education system. I now go on to explore the theoretical insights of Rosi Braidotti which are very much a continuation and an extension of the ideas of Deleuze and Guattari.

\section{Rosi Braidotti}

Braidotti is a contemporary social theorist, who has many interesting concepts that relate to both disability and in particular the disabled student. Most well known for her recent book The Posthuman (Braidotti, 2013), Braidotti extends the notions of 'the rhizome' and 'the nomad' that were first introduced by Deleuze and Guattari. Braidotti draws upon the concepts of the rhizome and the nomad in her questioning of the relevance of independence, and the call for the recognition of reciprocal interdependence in a framework which highlights the importance of positivity when talking about disability. Braidotti's work is being employed increasingly to make sense of the phenomenon of disability (Goodley et al., 2012.; Goodley et al., 2014; Harvey, 2017, 2018; Vandekinderen \& Roets, 2016). Braidotti's theorisation aligns well with an analysis of the student journey, as I will outline below.

For Braidotti, the disabled subject is a subject who is 'ever moving and becoming' (Roets \& Braidotti, 2012, p. 168). Therefore, this is:

An appeal for the re-conceptualisation of the nature of impaired bodies-and-minds as always in process, always in becoming and in relation to the collective. (Roets \& Braidotti, 2012, p. 165)

This is a powerful statement that is important for several reasons. Firstly, this conceptualisation highlights the way that viewing 'bodies-and-minds as always in process' necessitates less reliance on the things that disabled students might find difficult and instead places more focus on what the student might be capable of. Another way that this conceptualisation is useful is the focus it has upon the unsteady and unpredictable nature of the future. I argue this allows the period of higher education to be contextualised in the overall living of a life. Finally, this quotation states the importance of 'becoming in relation to the collective'. The notion of interdependence is a concept that has been used when analysing many aspects of disabled people's lives including; rehabilitation (Harvey, 2017, 2018), self-advocacy (Roets \& Goodley, 2008) and mental health problems (Vandekinderen \& Roets, 2016). I would suggest that a theorisation which leaves space for a view that does not position the subject as a singular and independent being is very useful when considering the educational journey of disabled students. Firstly, let us consider non-living 'objects'.

Increasingly, technological devices are playing a vital role in education. From just a cursory glance at a lecture theatre in the university in which I currently work, devices such as computers, over-head projectors, lecturerecording equipment and 'check-in' codes to ensure attendance data is correct can be found. This, together with the heavy reliance upon the student to be computer literate in order to access online tutorials, etc., highlights the changing landscape of higher education. When considering disabled students, the need to use technological devices in the form of dictaphones, mobile phones and cameras may be even greater. When added to the impact that walking aids can have on disabled people and especially on their sense of identity (Harvey, 2017), it is clear that a theorisation which acknowledges the importance of these nonhuman objects is important in reaching a thorough understanding of the disabled student journey.

The importance of human interdependence and companionship is also included in Braidotti's visualisation of contemporary life. Arguably, this is very relevant to the journey of disabled students. Certainly, during my journey through higher education, I found the support of my peers (both in lectures and in my every day negotiation of the university environment) to be very important. The university environment provided a space where I could socially interact with like-minded people. The importance of friendship and the formation of lasting social bonds demands mention. This may be especially important when considering the lives of people who may not have great opportunities to form such bonds, due in part to the stifling impact of disablism and ableism (Goodley, 2014).

A conceptualisation of the disabled student which acknowledges the 'always in process' and 'always in becoming' nature of the disabled person has important implications. Higher education institutions are increasingly seen as commercial organisation where education is a commodity that can be bought and sold (Altbach, 2015). It has been stated that disabled people have become dis- 
advantaged in the application of market forces in welfare and social care (Dodd, 2016). Given this, it would be sensible to suggest that disabled students may well struggle to a larger degree than their non-disabled peers in coming to terms with higher education that is governed by a 'neoliberal worldview' (Lawson, Sanders, \& Smith, 2015, p. 1182). However, if the disabled student was considered as a person who is 'in becoming', then arguably this turns the focus away from the 'acquisition' of higher education as a transactional and economic purchase, whereby value-for-money is demonstrated by assessment results. Under an 'always in becoming' framework, close attention is paid to the experience of attending university and the way it is contextualised into an overall life journey with a focus upon the benefits that it can give, which are arguably far more than economic.

Braidotti guides us towards a vision of disability and impairment which is wholly affirmative and strays far away from referring to disability as an 'individualised phenomenon (which) implies negativities, including pathology, pathos, social death, inertia, lack, limitation, loss, deficit and/or tragedy' (Roets \& Braidotti, 2012, p. 161). This notion of reconsidering disability as an affirmative identity is also relevant to the presence of disabled students in higher education institutions. Attending university is an important part of the life of any person (Newton \& McCunn, 2015) whether the person is disabled or not. Braidotti's affirmative conceptualisation of life enables a dynamic view of our education which sheds light on the most productive elements of attending university as a disabled student.

\section{Theorising the Disabled Student Journey}

Throughout this article I have critically explored the usefulness of social theory in making sense of the disabled student journey. I would suggest that social theory does indeed play a useful role in demystifying the student journey.

I have found social theory to be very useful when analysing my own journey through higher education. In particular, the non-linearity of my journey and the way I had to start university, withdraw from my course, and then start again a few years later seems to align well with the non-linearity of life that these theorists cite. Though I accept my experience of acquiring an impairment during my 20's is not typical of the experiences of many, I still believe that, whatever the cause, this non-linearity is common. This is confirmed in the research of others (Gale \& Parker, 2014; Madriaga et al., 2010; Nixon et al., 2018). Furthermore, the way that social theory allows us to stray away from taken-for-granted assumptions was very helpful. Reliance upon such assumptions would arguably lead to a lack of appreciation of the way that disabled learners could rise up against the restrictive barriers that seek to confine disabled people within limited spaces provided by a disablist society (Goodley, 2014; Watermeyer \& Swartz, 2016). I was very aware that my longstanding presence at university was unusual. Indeed, being in a position of (relative) authority in being the course lead for a university degree is also unusual and places me in a position of being able to challenge some of the restrictive barriers mentioned above. I suggest that analysing the experiences of disabled students through lenses such as those that query dualism; those that emphasise the use of power in society; and those that see life as the accumulation of experience would result in highly sophisticated analyses that are capable of being resonant to the lives of many.

Throughout this article, I have engaged with theoretical insights that were not intended to be used to increase understanding of the disabled student journey. However, I contended that theoretical insights come alive and are both hugely relevant and powerful when related to everyday situations and used as a tool for social change (Goodley et al., 2012). This is further exemplified by Steven Seidman (2016, p. ix) when he states in the preface to his book Contested Knowledge: Social Theory Today, that:

Sociological theory has all too often, especially in the last two decades, become isolated from public life and has chased the idol of science to a point of its own obscurity. Much sociological theory has abandoned a moral and political intention to engage the world as a medium of critical analysis and change. (Seidman, 2016, p. ix)

Following Seidman, I have sought to engage social theory, seeking to apply it as a medium of critical analysis and social change. I make no apologies for applying various theoretical ideas to interpret disabled students lives. Further, it has been stated that disability is the human condition which can shed light on a host of political, practical and social issues (Goodley, 2016). In this article, I have mobilised theoretical insights to establish how the equity of higher education may be examined from the perspective of disabled students.

In conclusion, I offer a simple model below (Figure 1) which is designed to demonstrate some of the ways that social theory can be used in the analysis of disabled student journeys. It is very much my hope that this model is of some use to disabled students as they seek to make their way through education.

Figure 1 is intended to underline the importance of acknowledging the influence of taken-for-granted assumptions; reflecting upon the importance of the influence of power in shaping disabled student journeys; and the importance of situating the experience of higher education into a life-course. I suggest that employing a social theoretical approach can be extremely helpful in reaching toward a sophisticated understanding of the disabled student journey.

The way that student journeys through higher education have been said to be simplified by analysis which involves social theory (Gale \& Parker, 2014; Strom, 2018; 


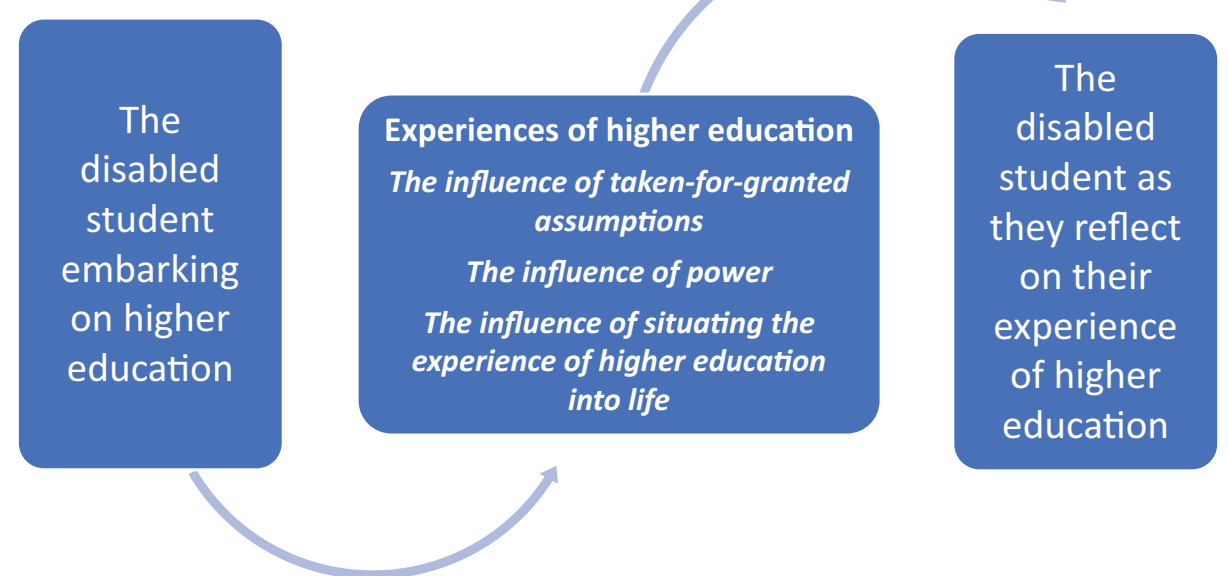

Figure 1. The way social theory can be used to understand a disabled student journey.

Taylor \& Harris-Evans, 2018; Wang, 2015) is important in the creation of this model. Consequently, I would suggest that a social-theory-inspired analysis of all student journeys would provide a healthy source of inspiration to those interested in undertaking such a journey in the future.

\section{Acknowledgments}

I would like to thank the disabled students I have come into contact with for sharing their insights with me.

\section{Conflict of Interests}

The author declares no conflict of interests.

\section{References}

Altbach, P. (2015). Higher education and the WTO: Globalization run amok. International Higher Education, 23. Retrieved from ejournals.bc.edu/ojs/ index.php/ihe/article/view/6593

Bessant, S. E. F., Robinson, Z. P., \& Ormerod, R. M. (2015). Neoliberalism, new public management and the sustainable development agenda of higher education: History, contradictions and synergies. Environmental Education Research, 21(3), 417-432. https://doi.org/ 10.1080/13504622.2014.993933

Braidotti, R. (2013). The Posthuman. Cambridge: Polity.

Campbell, F. K. (2009). Contours of ableism. The production of disability and abledness. contours of ableism: The production of disability and abledness. Basingstoke: Palgrave Macmillan. https://doi.org/ $10.1057 / 9780230245181$

Corker, M., \& Shakespeare, T. (2002). Disability/postmodernity: Embodying disability theory. London: Continuum.

Deleuze, G., \& Guattari, F. (1987). A thousand plateaus: Capitalism and schizophrenia. London: Continuum.
Dodd, S. (2016) Orientating disability studies to disablist austerity: Applying Fraser's insights. Disability \& Society, 31(2), 149-165.

Gale, T., \& Parker, S. (2014). Navigating change: A typology of student transition in higher education. Studies in Higher Education, 39(5), 734-753. https://doi.org/ 10.1080/03075079.2012.721351

Goodley, D. (2014). Dis/ability studies: Theorising disablism and ableism. London: Routledge.

Goodley, D. (2016). Disability studies: An interdisciplinary introduction. London: Sage.

Goodley, D., Hughes, B., \& Davis, L. (2012). Disability and social theory: New developments and directions. London: Palgrave.

Goodley, D., Lawthom, R., \& Runswick Cole, K. (2014). Posthuman disability studies. Subjectivity, 7(4), 342-361. https://doi.org/10.1057/sub.2014.15

Harpur, P. (2012). From disability to ability: Changing the phrasing of the debate. Disability \& Society, 27(3), 325-337. https://doi.org/10.1080/09687599. 2012.654985

Harvey, J. (2017). A sociological approach to acquired brain injury and identity. London: Routledge.

Harvey, J. (2018). Theorising everyday life after acquired brain injury. Disability \& Society, 33(1), 78-93.

Hughes, B. (2005). What can a Foucauldian analysis contribute to disability theory. In Foucalt and the governmint of disability (pp. 78-92). Ann Arbour: The University of Michigan Press.

Lawson, S., Sanders, K., \& Smith, L. (2015). Commodification of the information profession: A critique of higher education under neoliberalism. Journal of Librarianship and Scholarly Communication, 3(1), e112.

Lemke, T. (2015). New materialisms: Foucault and the "government of things". Theory, Culture \& Society, 32(4), 3-25. https://doi.org/10.1177/ 0263276413519340

Letherby, G., Scott, J., \& Williams, M. (2012). Objectiv- 
ity and subjectivity in social research. Objectivity and subjectivity in social research. London: Sage.

Madriaga, M., \& Goodley, D. (2010). Moving beyond the minimum: Socially just pedagogies and Asperger's syndrome in UK higher education. International Journal of Inclusive Education, 14(2), 115-131.

Madriaga, M., Hanson, K., Heaton, C., Kay, H., Newitt, S., \& Walker, A. (2010). Confronting similar challenges? Disabled and non-disabled students' learning and assessment experiences. Studies in Higher Education, 35(6), 647-658. https://doi.org/10.1080/ 03075070903222633

Mitchell, D. T. (2017). Disability, diversity, and diversion: Normalization and avoidance in higher education. In Disability, avoidance and the academy (pp. 9-21). London: Routledge.

Newton, G., \& McCunn, P. (2015). Student perception of topic difficulty: Lecture capture in higher education. Australasian Journal of Educational Technology, 31(3). https://doi.org/10.14742/ajet.1681

Nixon, E., Scullion, R., \& Hearn, R. (2018). Her majesty the student: Marketised higher education and the narcissistic (dis)satisfactions of the student-consumer. Studies in Higher Education, 43(6), 927-943.

Oliver, M. (2013). The social model of disability: Thirty years on. Disability \& Society, 28(7), 1024-1026. https://doi.org/10.1080/09687599.2013.818773

Olssen, M. (2016). Neoliberal competition in higher education today: Research, accountability and impact. British Journal of Sociology of Education, 37(1), 129-148. https://doi.org/10.1080/01425692. 2015.1100530

Price, J., \& Shildrick, M. (2002). Bodies together: Touch, ethics and disability. In Disability/postmodernity: Embodying disability theory (pp. 62-76). London: Continuum.

Roets, G., \& Braidotti, R. (2012). Nomadology and subjectivity: Deleuze, Guattari and critical disability studies. In Disability and social theory: New developments and directions (pp. 161-178). London: Palgrave.

Roets, G., \& Goodley, D. (2008). Disability, citizenship and uncivilized society: The smooth and nomadic qualities of self-advocacy. Disability Studies Quarterly, 28(4), 1-26. Retrieved from dsq-sds.org/ article/view/131\%5Cnfiles/17898/131.html

Seale, J., Georgeson, J., Mamas, C., \& Swain, J. (2015). Not the right kind of "digital capital"? An examination of the complex relationship between disabled students, their technologies and higher education institutions. Computers \& Education, 82, 118-128. Retrieved from http://10.0.3.248/j.compedu.2014. 11.007

Seidman, S. (2016). Contested knowledge: Social theory today. Chichester. John Wiley \& Sons.
Stocker, B. (2006). Routledge philosophy guidebook to Derrida on deconstruction. London: Routledge.

Strom, K. J. (2018). "That's Not Very Deleuzian": Thoughts on interrupting the exclusionary nature of "High Theory". Educational Philosophy and Theory, 50(1), 104-113. https://doi.org/10.1080/ 00131857.2017 .1339340

Student Loans Company. (2018). Information on DSA updates for practitioners-SFE Practitioners. Practitioners. Retrieved from www.practitioners.slc. co.uk/exchange-blog/2017/may/information-on-dsa -updates-for-practitioners

Taylor, C. A., \& Harris-Evans, J. (2018). Reconceptualising transition to higher education with Deleuze and Guattari. Studies in Higher Education, 43(7), 1254-1267. https://doi.org/10.1080/03075079.2016.1242567

Torrance, H. (2017). Blaming the victim: Assessment, examinations, and the responsibilisation of students and teachers in neo-liberal governance. Discourse: Studies in the Cultural Politics of Education, 38(1), 83-96. https://doi.org/10.1080/01596306. 2015.1104854

Tremain, S. L. (2015). Foucault and the government of disability. Ann Arbor, MI: University of Michigan Press.

Tripathi, T. P. (2012). Deconstructing disability, assistive technology: Secondary orality, the path to universal access (PhD dissertation). University of Southern California.

Van Trigt, P., Kool, J., \& Schippers, A. (2016). Humanity as a contested concept: Relations between disability and "being human". Social Inclusion, 4(4), 125. https://doi.org/10.17645/si.v4i4.754

Vandekinderen, C., \& Roets, G. (2016). The post(hu)man always rings twice: Theorising the difference of impairment in the lives of people with "mental health problems". Disability and Society, 31(1), 33-46. https://doi.org/10.1080/09687599.2015.1119037

Vehmas, S., \& Watson, N. (2014). Moral wrongs, disadvantages, and disability: A critique of critical disability studies. Disability and Society. https://doi.org/ 10.1080/09687599.2013.831751

Wang, C. L. (2015). Mapping or tracing? Rethinking curriculum mapping in higher education. Studies in Higher Education, 40(9), 1550-1559. https://doi.org/ 10.1080/03075079.2014.899343

Watermeyer, B., \& Swartz, L. (2016). Disablism, identity and self: Discrimination as a traumatic assault on subjectivity. Journal of Community \& Applied Social Psychology, 26(3), 268-276. https://doi.org/10.1002/ casp. 2266

Watson, N. (2012). Theorising the lives of disabled children: How can disability theory help? Children and Society, 26(3), 192-202. https://doi.org/10.1111/ j.1099-0860.2012.00432.x 


\section{About the Author}

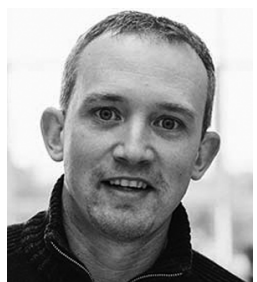

Jonathan Harvey (PhD) is a Lecturer in Education at Plymouth Marjon University and leads the BA (Hons) Special Educational Needs and Disability Studies course. His research has been conducted primarily with disabled people. His published research includes work which explores identity and disability; narrative methods; and the daily lives of chronically ill and disabled people. He is currently researching the complexities for disabled people who navigate the higher education system. 